\title{
Modulation of age-related changes in immune functions of protein-deficient senescence-accelerated mice by dietary nucleoside-nucleotide mixture supplementation
}

\author{
BY CLEMENT K. AMEHO ${ }^{1}$, ANDREW A. ADJEI ${ }^{2}$, KEIKO YAMAUCHI ${ }^{1}$, \\ ERIC K. HARRISON ${ }^{3}$, ANIL D. KULKARNI ${ }^{4}$, SEIJI SATO $^{5}$ \\ AND SHIGERU YAMAMOTO ${ }^{1 *}$ \\ ${ }^{1}$ Department of Nutrition, ${ }^{2}$ Department of Bacteriology and ${ }^{3}$ Department of Adult Health, Faculty of \\ Medicine, University of the Ryukyus, Nishihara, Okinawa 903-01, Japan \\ ${ }^{4}$ Surgical Research Institute, Department of Surgery, St Louis School of Medicine, Missouri, USA \\ ${ }^{5}$ Ohtsuka Pharmaceutical Co., Naruto 772, Japan
}

(Received 3 May 1996 - Revised 26 June 1996 - Accepted 29 August 1996)

\begin{abstract}
In the present study we examined the immune-enhancing effect of a nucleoside-nucleotide mixture on the non-specific T-cell immune functions of senescence-accelerated mice (SAM) fed on a lowprotein diet. The immune functions studied were in vitro thymic and splenic cell lymphoproliferative responses to phytohaemagglutinin, lipopolysaccharide and concanavalin $A$ and their production of interleukin-2 (IL-2) and interferon- $\gamma$ (INF- $\gamma$ ) in response to mitogen stimulation. SAMP8 mice aged 3 and 6 months were used. In each age group, mice were fed on diets containing either $50 \mathrm{~g}$ casein $/ \mathrm{kg}, 50 \mathrm{~g}$ casein $/ \mathrm{kg}$ supplemented with $5 \mathrm{~g}$ nucleoside-nucleotide mixture $/ \mathrm{kg}$ or $200 \mathrm{~g}$ casein/kg for 3 weeks. The supplemented 3 - and 6-month-old mice had higher $(P<0.05)$ thymic and splenic cell counts compared with the low-protein group. In both age groups of mice, concanavalin $A$ induced higher $(P<0.05)$ total thymic and splenic lymphoproliferative responses for the nucleoside-nucleotide mixture-supplemented group compared with the $50 \mathrm{~g}$ casein $/ \mathrm{kg}$ dietary groups. Thymic and splenic production of IL-2 was higher for the 3-month-old mice in both the supplemented and the $200 \mathrm{~g}$ casein $/ \mathrm{kg}$ dietary groups. INF- $\gamma$ production in the supplemented 3month-old group and the 6-month-old $200 \mathrm{~g}$ casein/kg dietary group was higher $(P<0.05)$ compared with the other groups. Overall the supplemented 3-month-old mice exhibited both higher lymphoproliferative responses and production of cytokines compared with the supplemented 6month-old mice. The results indicate that early nucleoside-nucleotide mixture supplementation may enhance the immune response in protein-deprived SAMP8 mice.
\end{abstract}

Nucleoside-nucleotide mixture: Immune function: SAMP8

We have previously demonstrated that dietary sources of nucleosides and nucleotides are important for the maintenance and enhancement of cellular immunity. Nucleotide-free diets (NFD) have been found to suppress T-cell response to mitogens, increase cardiac allograft survival (Van Buren et al. 1983); decrease delayed hypersensitivity to chemical and bacterial antigens and xenoantigens (Kulkarni et al. 1987); and decrease interleukin-2 (IL-2) production (Van Buren et al. 1985). In addition NFD decrease the host resistance to systemic Staphylococcus aureus infection (Kulkarni et al. 1986; Adjei et al. 1993) and Candida albicans in mice (Fanslow et al. 1988). The effects on the humoral immune system have also been well documented. It has been shown that dietary nucleotides and

\footnotetext{
* For reprints.
} 
nucleosides increase antibody production, interferon- $\gamma$ (INF- $\gamma$ ) and B-cell number in both human subjects and mice (Jyonouchi et al. 1992; Kemen et al. 1992). Thus, one can reasonably speculate that nucleic acids and their components have stimulating effects on the immune system.

The senescence-accelerated mouse (SAM) derived from AKR/J mice is a murine model of accelerated ageing and consists of substrains which are either resistant (SAMR) or prone (SAMP) to rapid senescence (Takeda et al. 1981). SAMP mice undergo normal growth and development for about 2 months, after which they show age-related changes in immune characteristics (Takeda et al. 1991). Among several abnormal immune activities, SAMP mice show an early decline in T-helper functions leading to an impaired in vitro anti-sheep erythrocyte antibody response (Hosokawa et al. 1987a, $b$; Yoshioka et al. 1989).

Although most studies have focused on the cellular bases of impairment of the immune system in SAM mice, no studies to our knowledge have been done on the use of immunomodulatory nutrients to improve the immune system of SAMP mice, which provide a murine model suitable for the study of progressive decline of immune viability with age. In addition to the decline in immune functions, ageing in association with protein malnutrition (PM) leads to further degeneration of immune functions. The present studies were designed to examine the effect of dietary nucleoside-nucleotide mixtures on non-specific T-cell immune responses as a measure of the potential of the mixture to enhance T-helper cell $\left(T_{H}\right)$ function using SAMP8 mice. The immune variable most often studied in age-related decline in immune functions is the ability of lymphocytes to proliferate in response to foreign stimuli, such as antigens or mitogens. Thus we measured lymphocyte response to mitogens and production of IL-2 and INF- $\gamma$ of SAMP8 mice fed on a low protein diet to simulate the dual conditions of PM and ageing. These two cytokines are indicative of $T_{H}$ function. We studied these mice because they represent a rapid and easily accessible model of ageing.

\section{MATERIALS AND METHODS}

\section{Animals and diets}

Two age groups of SAMP8 mice were studied. Specific-pathogen-free 3-month-old and 6month-old male SAMP8 mice of average weight $22.3 \mathrm{~g}$ and $26.8 \mathrm{~g}$ respectively, born and raised in our laboratory, were used. The mice were kept in a room with constant temperature $\left(25 \pm 2^{\circ}\right)$ and humidity $(50-70 \%)$ with a $12 \mathrm{~h}$ light period (from 08.00 to 20.00 hours). Mice were maintained on a standard chow diet (Nihon Clear, Osaka, Japan) containing $(\mathrm{g} / \mathrm{kg})$ protein 255 and fat 43 during their respective growth periods. At 3 months and 6 months respectively, mice from each age group were divided into three dietary groups and fed on isoenergetic and isonitrogenous experimental diets for 3 weeks. The diets were: nucleic acid-free $50 \mathrm{~g}$ casein $/ \mathrm{kg}$ (low-protein diet, LPD), $50 \mathrm{~g}$ casein $/ \mathrm{kg}$ supplemented with $5 \mathrm{~g}$ nucleoside-nucleotide mixture/kg (LPD + NNM) or nucleic acidfree $200 \mathrm{~g}$ casein $/ \mathrm{kg}$ diet (Control). Table 1 shows the composition of the diets. The conditions of the study were based on the results of preliminary studies which indicated that $5 \mathrm{~g}$ of this particular mixture $/ \mathrm{kg}$ (Table 1) and a 3-week period of feeding offered the maximum response. Mice were allowed free access to food and water and body weights were monitored for 3 weeks. Diets and water were renewed every morning between 08.00 and 10.00 hours. Animal care was in compliance with Applicable Guidelines from Ryukyus University Policy on Animal Care and Use. At the end of the period, the following experiments were performed: thymic and splenic lymphocyte responsiveness to a battery of mitogens and production of IL-2 and INF- $\gamma$. 
Table 1. Composition of experimental diets $(\mathrm{g} / \mathrm{kg})$

\begin{tabular}{llcc}
\hline \hline & \multicolumn{3}{c}{ Diet } \\
\cline { 2 - 4 } Ingredient & Control & LPD & LPD + NNM \\
\hline Casein & $200 \cdot 0$ & $50 \cdot 0$ & $50 \cdot 0$ \\
Starch & 444.0 & 544.0 & $543 \cdot 0$ \\
Sucrose & 222.0 & 272.0 & $272 \cdot 0$ \\
Mineral mixture* & 50.0 & 50.0 & $50 \cdot 0$ \\
Vitamin mixture† & 10.0 & 10.0 & $10 \cdot 0$ \\
Cellulose & 20.0 & 20.0 & 20.0 \\
Maize oil & 50.0 & 50.0 & 50.0 \\
Glycine & 4.0 & 4.0 & - \\
NNM $\ddagger$ & - & - & 5.0 \\
\hline \hline
\end{tabular}

LPD, low-protein diet; NNM, nucleoside-nucleotide mixture.

* Obtained from Oriental Yeast Co., Tokyo, Japan. The composition was as follows (mg/kg): $\mathrm{CaHPO}_{4} .2 \mathrm{H}_{2} \mathrm{O} 7820$, $\mathrm{KHPO}_{4} 12800, \mathrm{NaH}_{2} \mathrm{PO}_{4} 4680, \mathrm{NaCl} 2330$, Ca lactate 17550 , Fe citrate $1590, \mathrm{MgSO}_{4} 3590, \mathrm{ZnCO}_{3} 55$, $\mathrm{MnSO}_{4} .6 \mathrm{H}_{2} \mathrm{O} 60, \mathrm{CuSO}_{4} .5 \mathrm{H}_{2} \mathrm{O} 15, \mathrm{KI} 5$.

† Obtained from Oriental Yeast Co. The composition was as follows $(\mathrm{mg} / \mathrm{kg}$ ): thiamin $\mathrm{HCl} 12$, riboflavin 40, pyridoxine $\mathrm{HCl} 8$, cyanocobalamin 50, ascorbic acid 300, D-biotin 0.2 , pteroylglutamic acid 2, calcium pantothenate $5, p$ amino-benzoic acid 50, nicotinic acid 60 , inositol 60 , choline chloride 2000 , dl- $\alpha$ tocopherol acetate 50 , menadione 52 , retinyl acetate 5000 and ergocalciferol 1000 .

‡ Obtained from Ohtsuka Phamaceutical Co., Tokushima, Japan. The composition was as follows ( $\mathrm{g} / \mathrm{l})$ : inosine 230 , cytidine 210 , guanidine monophosphate $2 \mathrm{Na} 350$, uridine 160 , thymidine 50 .

\section{Cell preparation}

Mice were killed by cervical dislocation, thymus and spleen aseptically resected, placed in sterile petri dishes containing RPMI 1640 (Sigma Chemical Co., Sigma, St. Louis, MO, USA), penicillin (100000 U/1) and streptomycin $(50 \mathrm{U} / \mathrm{ml})$ and stored on ice. Single-cell suspensions were obtained by teasing the tissues through 50-mesh stainless steel wire screens with the aid of plastic disposable syringe pistons into ice-cold RPMI 1640. The suspensions were treated with $0.1 \mathrm{M}$-Tris $\mathrm{HCl}\left(\mathrm{pH} \mathrm{7.2)}\right.$ containing $8 \mathrm{~g} / 1$ Tris $\mathrm{NH}_{4} \mathrm{Cl}$ to lyse erythrocytes, and centrifuged at $200 \mathrm{~g}$ for $5 \mathrm{~min}$ at $4^{\circ}$. Cell pellets were then washed three times in RPMI 1640, resuspended in complete RPMI 1640 (containing $20 \mathrm{mM}$-HEPES, $2 \mathrm{mM}$-glutamine, $100 \mu \mathrm{g}$ gentamycin $/ \mathrm{ml}, 100 \mathrm{U}$ streptomycin $/ \mathrm{ml}$, and $100 \mathrm{ml}$ heatinactivated fetal calf serum/1 (Sigma), and cell viability determined by trypan blue exclusion. Cell suspensions were enumerated using a haemocytometer and then adjusted appropriately.

Spleen and thymic cells $\left(5 \times 10^{5}\right.$ cells per well) in complete RPMI $1640\left(2.5 \times 10^{3}\right.$ cells $/ \mu \mathrm{l})$ were dispensed into ninety-six-well flat-bottomed Falcon microtitre plates and cultured in triplicate for $30 \mathrm{~h}$ at $37^{\circ}$ in a humidified $50 \mathrm{ml} / 1 \mathrm{CO}_{2}$ incubator in the presence of $5 \mu \mathrm{g}$ concanavalin A (Con A)/ml (Sigma), $10 \mu \mathrm{g}$ phytohaemagglutinin (PHA)/ml (Sigma), or $40 \mu \mathrm{g}$ lipopolysaccharide (LPS)/ml, (Sigma). Cells cultured without mitogens served as negative controls. Lymphocyte blastogenic response was determined by the method of Hansen et al. (1989), which is a modification of the method of Mossman (1983). Briefly, to a lymphocyte-containing culture medium in the microplate, $25 \mu 13$, (4, 5dimethylthiazol-2-yl) 2,5-diphenyltetrazolium bromide (MTT) $(1 \mathrm{mg} / \mathrm{ml})$ was added to each well. After $1 \mathrm{~h}$ incubation at $37^{\circ}$ in a humidified $\mathrm{CO}_{2}$ incubator, $100 \mu \mathrm{l}$ of an extraction buffer was added. After overnight incubation, the absorbances were measured at $570 \mathrm{~nm}$ by a Titer-tech (Dynatech, USA) ninety-six-well multi-scanner using the extraction buffer as the blank. The mitogen response was calculated as the mitogen stimulated: spontaneous lymphoproliferative response ratio, and reported as the stimulation index (SI). 
Optimal conditions required for application of MTT had been previously determined before the start of the experiment.

\section{Thymic and splenic cell counts}

Total thymic and splenic cell counts were determined before lysis. The cells were diluted ten times with Turk solution $(1 \mathrm{ml} 10 \mathrm{~g} / 1$ gentian violet and $1 \mathrm{ml} 995 \mathrm{~g} / 1$ acetic acid were diluted to 1 litre with distilled water) and the number was determined by counting them in a haemocytometer.

\section{Interleukin-2 and interferon- $\gamma$ production}

Spleen and thymus cells $\left(5 \times 10^{5}\right.$ cells/well $)$ in complete RPMI $1640\left(2.5 \times 10^{3}\right.$ cells $\left./ \mu \mathrm{l}\right)$ were dispensed into ninety-six-well flat-bottomed Falcon microtitre plates and cultured in triplicate for $30 \mathrm{~h}$ at $37^{\circ}$ in a humidified $50 \mathrm{ml} / 1 \mathrm{CO}_{2}$ incubator in the presence of $5 \mu \mathrm{g} / \mathrm{ml}$ Con $\mathrm{A}$, as described earlier. At the end of the incubation period, triplicate supernatant fractions were collected, pooled and stored at $-80^{\circ}$ for IL- 2 and INF- $\gamma$ analysis. IL- 2 and INF- $\gamma$ were quantified with commercial mouse IL-2 and INF- $\gamma$ ELISA kits (BectonDickinson, Maryland, USA), following the manufacturer's instructions. The inter-assay and intra-assay CV were $<10 \%$. The limits of sensitivity of the assays were $<15 \mathrm{pg} / \mathrm{ml}$ for INF- $\gamma$ and $<3 \mathrm{pg} / \mathrm{ml}$ for IL-2.

\section{Chemicals}

MTT (Wako Chemical Co., Tokyo, Japan) was dissolved to a concentration of $5 \mathrm{mg} / \mathrm{ml}$ in sterile phosphate-buffered saline, $\mathrm{pH} 7 \cdot 2$, at room temperature. The solution was filtersterilized (millipore $0.22 \mu \mathrm{m}$ ) and stored at $4^{\circ}$ in a dark bottle. SDS and $\mathrm{N}, \mathrm{N}-$ dimethylformamide (DMF) were obtained from Wako Chemical Co. The composition of the extraction buffer was as follows: $200 \mathrm{~g} \mathrm{SDS} / 1$ was dissolved at $37^{\circ}$ in a solution of $500 \mathrm{~g} / 1$ each of DMF and demineralized water. The $\mathrm{pH}$ was adjusted to 4.7 by adding $25 \mathrm{~g} / 1$ of $800 \mathrm{~g} / 1$ acetic acid and $25 \mathrm{~g} / 1$ of $1 \mathrm{M}-\mathrm{HCl}$.

\section{Statistical analysis}

Statistical analyses were performed using ANOVA. Duncan's multiple range test was used to determine significant differences among means at $P<0.05$.

\section{RESULTS}

Weight gain, tissue weight and cell counts

Table 2 shows the effect of the diets on the body weights of both age groups of mice. At the end of 3 weeks on the diets, in both age groups of mice, the LPD and the LPD + NNM groups had lost weight. Mice on the Control diet had gained weight which was significantly higher $(P<0.05)$ compared with the other dietary groups.

Tables 3 and 4 show the splenic and thymic weights as well as the mean total cell counts of both organs of the 3-month-old and 6-month-old mice respectively. In both age groups of mice, the corresponding organ weights were similar among the groups. However, both the LPD + NNM and Control groups had significantly higher $(P<0.05)$ mean total spleen and thymus counts than the LPD group in both age groups. A significant feature 
Table 2. Body-weight changes in 3-month-old and 6-month-old mice fed on a low-protein diet (LPD), LPD plus a nucleoside-nucleotide mixture (NNM) or a control diet for 3 weeks* (Mean values with their standard errors for twelve mice per dietary group)

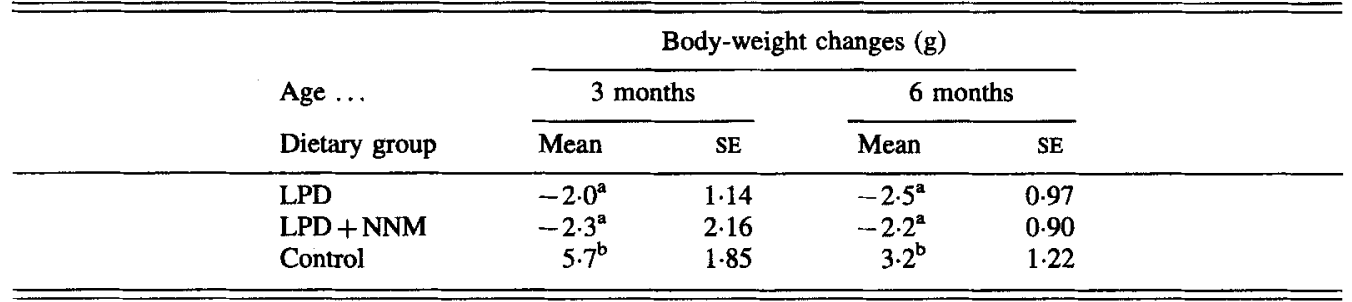

${ }^{\mathrm{a}, \mathrm{b}}$ Mean values within a column with unlike superscript letters were significantly different, $P<0.05$.

* For details of diets, see Table 1 .

Table 3. Organ weights and cell counts in 3-month-old SAMP8 mice fed on a low-protein diet ( $L P D), L P D$ plus a nucleoside-nucleotide mixture (NNM) or a control diet for 3 weeks*

(Mean values with their standard errors for twelve mice per dietary group)

\begin{tabular}{|c|c|c|c|c|c|c|c|c|}
\hline \multirow[b]{2}{*}{ Dietary group } & \multicolumn{2}{|c|}{ Splenic weight (g) } & \multicolumn{2}{|c|}{$\begin{array}{l}\text { Total splenic } \\
\text { count (cells } / \\
\text { tissue) } \times 10^{6}\end{array}$} & \multicolumn{2}{|c|}{$\begin{array}{c}\text { Thymic weight } \\
\text { (g) }\end{array}$} & \multicolumn{2}{|c|}{$\begin{array}{l}\text { Total thymic } \\
\text { count (cells } / \\
\text { tissue) } \times 10^{6}\end{array}$} \\
\hline & Mean & $\mathrm{SE}$ & Mean & SE & Mean & $S E$ & Mean & SE \\
\hline LPD & 0.08 & 1.01 & $4.86^{a}$ & 0.93 & 0.02 & 0.01 & $4.72^{a}$ & 3.45 \\
\hline LPD + NNM & 0.09 & 0.01 & $9.86^{b}$ & 1.20 & 0.03 & 0.04 & $9 \cdot 89^{b}$ & 2.97 \\
\hline Control & 0.11 & 0.10 & $9.95^{b}$ & 1.11 & 0.03 & 0.01 & $9 \cdot 53^{b}$ & 2.44 \\
\hline
\end{tabular}

${ }^{a, b}$ Mean values within a column with unlike superscript letters were significantly different, $P<0.05$.

* For details of diets, see Table 1 .

Table 4. Organ weights and cell counts in 6-month-old SAMP8 mice fed on a low-protein diet (LPD), LPD plus a nucleoside-nucleotide mixture (NNM) or a control diet for 3 weeks*

(Mean values with their standard errors for twelve mice per dietary group)

\begin{tabular}{|c|c|c|c|c|c|c|c|c|}
\hline \multirow[b]{2}{*}{ Dietary groups } & \multicolumn{2}{|c|}{ Splenic weight (g) } & \multicolumn{2}{|c|}{$\begin{array}{l}\text { Total splenic } \\
\text { count (cells/ } \\
\text { tissue) } \times 10^{6}\end{array}$} & \multicolumn{2}{|c|}{$\begin{array}{c}\text { Thymic weight } \\
\text { (g) }\end{array}$} & \multicolumn{2}{|c|}{$\begin{array}{l}\text { Thymic count } \\
\text { (cells } / \\
\text { tissue) } \times 10^{6}\end{array}$} \\
\hline & Mean & SE & Mean & SE & Mean & $\mathrm{SE}$ & Mean & SE \\
\hline LPD & 0.07 & 0.01 & $3.06^{\mathrm{a}}$ & 1.08 & 0.01 & 0.02 & $4 \cdot 61^{\mathrm{a}}$ & 0.72 \\
\hline LPD + NNM & 0.09 & 0.01 & $8 \cdot 55^{b}$ & 1.63 & 0.02 & 0.04 & $8 \cdot 63^{b}$ & 4.59 \\
\hline Control & 0.10 & 0.10 & $8.76^{b}$ & 1.23 & 0.02 & 0.01 & $8 \cdot 11^{b}$ & $2 \cdot 40$ \\
\hline
\end{tabular}

${ }^{\text {a.b }}$ Mean values within a column within unlike superscript letters were significantly different, $P<0.05$.

* For details of diets, see Table 1. 
observed in the LPD + NNM dietary groups of both ages was the presence of numerous small thymic and splenic cells.

\section{Lymphoproliferative responses}

Fig. 1 shows the thymic lymphoproliferative responses of 3-month-old (Fig. 1(a)) and 6month-old (Fig. 1(b)) SAMP8 mice expressed as SI. In both age groups PHA and LPS responses were similar among the dietary groups. With Con $\mathrm{A}$, in both age groups, the LPD + NNM groups exhibited responses which were significantly higher $(P<0.05)$ compared with the LPD groups. Responses were similar between the LPD and the Control groups in both age groups.

( a )

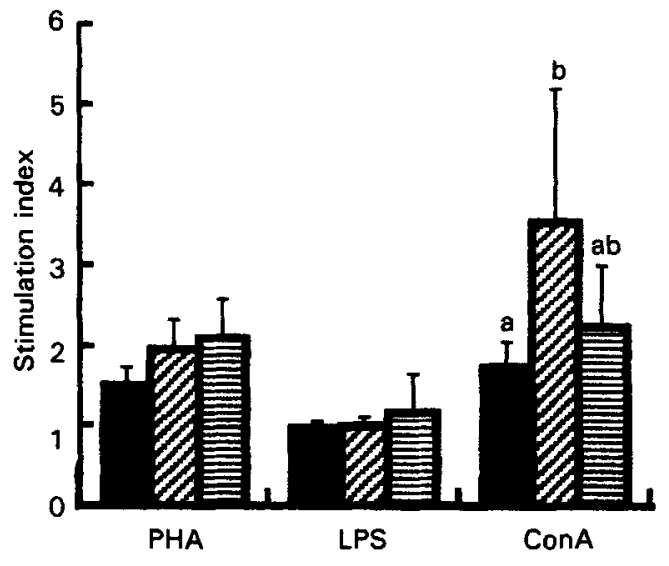

(b)

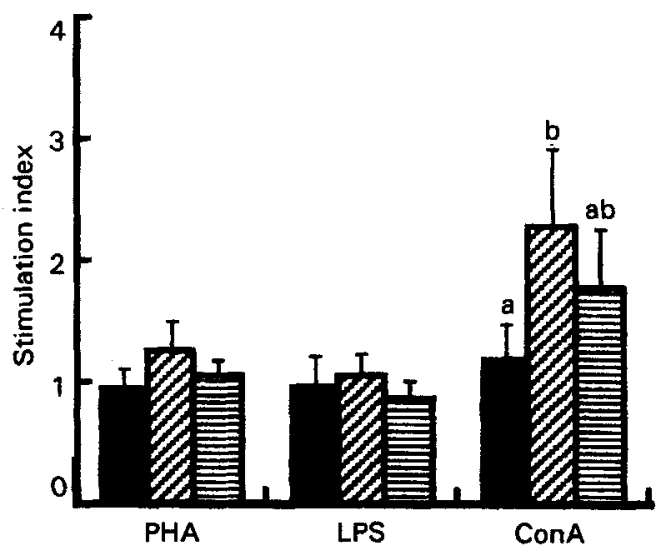

Fig. 1. Thymic stimulation index of (a) 3-month-old and (b) 6-month-old SAMP8 mice fed on a low-protein diet ( $\square$ ), a low-protein diet plus a nucleoside-nucleotide mixture (包), or a control diet (目) for 3 weeks. Cell suspensions were cultured with phytohaemagglutinin (PHA), lipopolysaccharide (LPS) or concanavalin A (Con A) for $30 \mathrm{~h}$. For details of procedures, see pp. 796-797. Values are means for twelve mice per dietary group, with their standard errors represented by vertical bars. ${ }^{a, b}$ Mean values not sharing a common superscript letter were significantly different, $P<0.05$. 


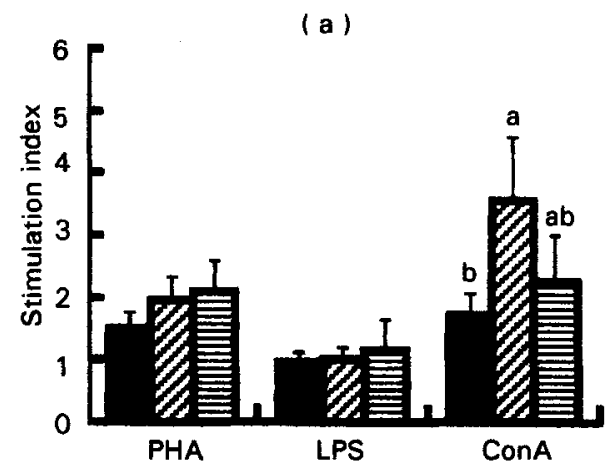

(b)

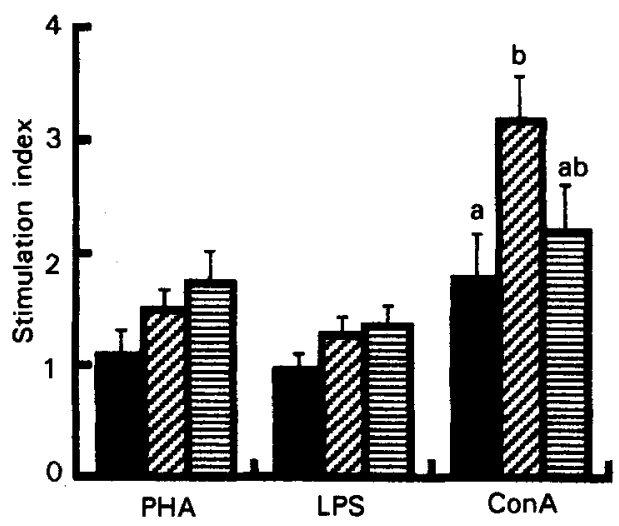

Fig. 2. Splenic stimulation index of (a) 3-month-old and (b) 6-month-old SAMP8 mice fed on a low-protein diet ( $\square$ ), a low-protein diet plus a nucleoside-nucleotide mixture (2), or a control diet (뭅) for 3 weeks. Cell suspensions were cultured with phytohaemagglutinin (PHA), lipopolysaccharide (LPS) or concanavalin A (Con A) for $30 \mathrm{~h}$. For details of procedures, see pp. 796-797. Values are means for twelve mice per dietary group, with their standard errors represented by vertical bars. ${ }^{\mathrm{a} b} \mathrm{M}$ Mean values not sharing a common letter were significantly different, $P<0.05$.

Fig. 2 shows the splenic lymphoproliferative responses of 3-month-old (2(a)) and 6month-old (Fig. 2(b)) SAMP8 mice expressed as SI. In both age groups of mice, PHA and LPS exhibited similar responses among the dietary groups. With Con A, the LPD + NNM groups exhibited responses which were higher $(P<0.05)$ than those of the LPD groups. Responses were similar between the LPD and the Control groups in both age groups.

\section{In vitro cytokine production}

Table 5 shows the results of in vitro cytokine production by Con A-stimulated thymic and splenic cells of both age groups of mice. Between the age groups in the LPD + NNM group, the 3 -month-old mice showed higher production of both cytokines $(P<0.05)$ compared with the 6-month-old mice. Within the Control group, the 3-month-old mice showed a higher production of IL-2 $(P<0.05)$ in both organs compared with the 6-monthold mice. However, the 6-month-old mice showed a higher production of INF- $\gamma(P<0.05)$ compared with the 3-month-old mice in both organs. Within the LPD group, production of 
Table 5. In vitro thymic and splenic cell production of interleukin-2 (IL-2) and interferon- $\gamma$ $(I N F-\gamma)(n g / m l)$ by SAMP8 mice fed on a low-protein diet (LPD), LPD plus a nucleosidenucleotide mixture (NNM) or a control diet for 3 weeks*

(Mean values with their standard errors for twelve mice per dietary group)

\begin{tabular}{|c|c|c|c|c|c|c|c|c|c|}
\hline \multirow[b]{3}{*}{ Dietary group } & \multirow[b]{3}{*}{ Age (months) } & \multicolumn{4}{|c|}{ Thymus } & \multicolumn{4}{|c|}{ Spleen } \\
\hline & & \multicolumn{2}{|c|}{$\mathrm{IL}-2$} & \multicolumn{2}{|c|}{ INF- $\gamma$} & \multicolumn{2}{|c|}{ IL-2 } & \multicolumn{2}{|c|}{ INF- $\gamma$} \\
\hline & & Mean & SE & Mean & SE & Mean & $\mathrm{SE}$ & Mean & SE \\
\hline \multirow[t]{2}{*}{ LPD } & 3 & $3.08^{a}$ & 1.92 & $2.41^{\mathrm{a}}$ & 0.45 & $4.67^{\mathrm{a}}$ & 1.44 & $3 \cdot 10^{\mathrm{a}}$ & 1.60 \\
\hline & 6 & $1 \cdot 17^{\mathrm{a}}$ & 0.75 & $2.44^{\mathrm{a}}$ & 0.79 & $3.52^{\mathrm{a}}$ & 1.38 & $4.19^{b}$ & $2 \cdot 18$ \\
\hline \multirow[t]{2}{*}{ LPD + NNM } & 3 & $8.58^{\mathrm{b}}$ & $1 \cdot 16$ & $7.84^{\mathrm{b}}$ & $2 \cdot 33$ & $15.43^{b}$ & 3.29 & $12.06^{\mathrm{c}}$ & 2.65 \\
\hline & 6 & $4.57^{\mathrm{a}}$ & 0.77 & $3.00^{\mathrm{a}}$ & 0.50 & $4 \cdot 54^{a}$ & 1.43 & $7.83^{\mathrm{b}}$ & 1.57 \\
\hline \multirow[t]{2}{*}{ Control } & 3 & $6.36^{\mathrm{b}}$ & 1.85 & $3 \cdot 18^{\mathrm{a}}$ & 1.16 & $12.88^{\mathrm{b}}$ & 2.44 & $3.72^{a}$ & 1.54 \\
\hline & 6 & $1.71^{\mathrm{a}}$ & 0.56 & $5.46^{\mathrm{b}}$ & 1.22 & $3 \cdot 34^{a}$ & 1.96 & $10 \cdot 26^{\mathrm{c}}$ & 2.35 \\
\hline
\end{tabular}

a,b,c Mean values within a column with unlike superscript letters were significantly different, $P<0.05$.

* For details of diets and procedures, see Table 1 and pp. 796-798.

both cytokines was low and similar between the age groups, except for production of INF- $\gamma$ by splenocytes which was higher $(P<0.05)$ in the 6-month-old compared with the 3month-old mice. Between the LPD and LPD + NNM groups, the 3-month-old LPD + NNM group showed significantly higher $(P<0.05)$ production of both cytokines overall. In both organs, the 3 -month-old Control group produced more IL-2 $(P<0.05)$, while the 6-month-old Control group produced more INF- $\gamma$ than the corresponding age groups in the LPD groups.

\section{DISCUSSION}

Body-weight loss and lymphoid atrophy are prominent features of protein-energy malnutrition (PEM) (Chandra, 1991), and cellular immunity is most devastated by severe malnutrition (Field et al. 1991). The target lymphocyte subpopulation appears to be the $\mathrm{T}_{\mathrm{H}}$ cells and is associated with decreased production of lymphokines, such as IL-2 which is necessary for the propagation of normal $\mathrm{T}$-cell mediated immune responses (Chandra, 1983). In the present study this was reflected in the low T-cell responses shown by the LPD group. However, our study utilizing levels of protein intake that resulted in weight loss, showed in these mice that early dietary NNM supplementation in protein deficiency may help in maintaining immune functions as evidenced by the increased productions of IL-2 and INF- $\gamma$ in the 3-month-old LPD + NNM group. In the 6-month-old mice, although supplementation led to significant increases in the total thymic and splenic cell counts, neither lymphoproliferative response nor the production of IL-2 and INF- $\gamma$ were significantly different from control levels. This observation is astounding and suggests that despite the enhanced lymphoproliferation, IL-2 and INF- $\gamma$-producing cells are dysfunctional or underrepresented at this apparently late stage of supplementation. Whether the defect represents a delay in maturation or a more permanent alteration remains to be elucidated, and whether this defect can be permanently rectified with early and prolonged NNM supplementation is not yet known. Toichi et al. (1994) reported that the transfer of purified T-cells from young SAMP mice to "aged" SAMP mice led to restoration of the $T$-dependent antibody production through normalization of $T_{H}$ function. The present study showed an improvement in the non-specific $T_{H}$ function of proteindeficient "aged" mice with dietary NNM supplementation and its importance lies in the 
peculiar growth characteristics of these mice which show normal growth for about 2 months and then show an age-related defect in $T_{H}$ function leading to defective $T$ dependent antibody response.

Many studies using stimulated splenocytes from mice show an age-related increase in INF- $\gamma$ production (Heine \& Adler, 1977; Saxena et al. 1988; Hobbs et al. 1993), while decreasing mitogen-induced IL-2 synthesis with advancing age has been described in both human subjects and mice (Thoman \& Weigle, 1981, 1985; Negoro et al. 1986). In the present studies we also observed an increase in INF- $\gamma$ production by thymic and splenic cells of the 6-month-old Control mice and by the splenic cells of the LPD groups (Table 5). Increased INF- $\gamma$ production in ageing has been associated with inhibition of T-cell proliferation (Hobbs et al. 1993). This increase in INF- $\gamma$ production among the 6-monthold mice in the unsupplemented dietary group, together with age, may be the factors responsible for the low lymphoproliferation and IL-2 production observed in these groups. Considering the rather low production of thymic cytokines and splenic IL-2 in the LPD dietary group, it is conceivable that the dietary effect may have been the most important predisposing factor influencing this depression in T-cell function. However, the increased production of both cytokines in the 3-month-old compared with the 6-month-old mice in the LPD + NNM group demonstrate the enhancing effect of early dietary NNM supplementation on IL-2 and INF- $\gamma$ production.

To our knowledge, this is the first report that has assessed the immunopotentiating effect of NNM on the T-cell lymphoproliferative response to mitogen in SAM mice. These findings suggest that early dietary supplementation with NNM may provide the possibility of modulating the observed decline in T-cell proliferative response with ageing.

The authors would like to thank Takafumi Suzuki for technical assistance in preparing the manuscript.

\section{REFERENCES}

Adjei, A. A., Takamine, F., Yokoyama, H., Shiokawa, K., Matsumoto, Y., Asato, L., Shinjo, S., Imamura, T. \& Yamamoto, S. (1993). The effects of oral RNA and intraperitoneal nucleoside-nucleotide administration on methicillin-resistant Staphylococcus aureus infection in mice. Journal of Parenteral and Enteral Nutrition 17, $148-152$.

Chandra, R. K. (1983). Nutrition, immunity and infection: present knowledge and future directions. Lancet 1, 688-691.

Chandra, R. K. (1991). Nutrition and immunity: lessons from the past and new insights into the future. American Journal of Clinical Nutrition 253, 1087-1101.

Fanslow, W. C., Kulkarni, A. D., Van Buren, C. T. \& Rudolph, F. B. (1988). Effect of nucleotide restriction and supplementation on resistance to experimental candidiasis. Journal of Parenteral and Enteral Nutrition 12, 49-52.

Field, C. J., Gougeon, R. \& Marliss, E. B. (1991). Changes in the circulating leukocytes and mitogen responses during very-low all-protein diets. American Journal of Clinical Nutrition 54, 123-129.

Hansen, M. B., Nielsen, S. E. \& Berg, K. (1989). Re-examination and further development of a precise and rapid dye method for measuring cell growth and kill. Journal of Immunology Methods 119, 203-210.

Heine, J. W. \& Addler, W. H. (1977). The quantitative production of interferon by mitogen stimulated mouse lymphocytes as a function of age and its effect on the lymphocytes proliferative response. Journal of Immunology 118, 1366-1369.

Hobbs, M. V., Weigle, W. O., Noonan, D. J., Torbett, B. E., McEvilly, R. J., Koch, R. J. Cardenas, G. J. \& Ernst, D. N. (1993). Patterns of cytokine gene expression by CD4 + T cells from young and old mice. Journal of Immunology 150, 3602-3614.

Hosokawa, T., Hosono, M., Hanada, K., Aoike, A., Kawai, K. \& Takeda, T. (1987a). Immune responses in newly developed short-lived SAM mice. I. Age-associated early decline in immune activities of cultured spleen cells. Immunology 62, 419-423. 
Hosokawa, T., Hosono, M., Higuchi, K., Aoike, A., Kawai, K. \& Takeda, T. (1987b). Immune responses in newly developed short-lived SAM mice. II. Selectively impaired T-helper cell activity in in vitro antibody response. Immunology 62, 425-429.

Jyonouchi, H., Hill, R. J. \& Good, R. A. (1992). RNA/nucleotide enhances antibody production in vitro and is moderately antigenic to murine spleen lymphocytes. Proceedings of the Society for Experimental Biology and Medicine 20, 101-108.

Kemen, M., Senkal, M. \& Hoffman, H. H. (1992). Influence of arginine, RNA and omega-3-fatty acid supplemental enteral nutrition on postoperative humoral immunity in cancer patients undergoing major upper gastrointestinal surgery. Clinical Nutrition 11, Suppl., 123 Abstr.

Kulkarni, A. D., Fanslow, W. C., Rudolph, F. B. \& Van Buren, C. T. (1986). Effect of dietary nucleotides on response to bacterial infections. Joumal of Parenteral and Enteral Nutrition 10, 169-171.

Kulkarni, A. D., Fanslow, W. C., Rudolph, F. B. \& Van Buren, C. T. (1987). Modulation of delayed hypersensitivity in mice by dietary nucleotide restriction. Transplantation 44, 847-849.

Mossman, T. (1983). Rapid colorimetric assay for cellular growth and survival: application to proliferation and cytotoxic assay. Journal of Immunology Methods 65, 55-63.

Negoro, S., Hara, H., Miyata, S., Saiki, O., Tanaka, T., Yoshizaki, K., Igarashi, T. \& Kishimoto, S. (1986). Mechanisms of age-related decline in antigen-specific T-cell proliferative response: $\mathbb{L}-2$ receptor expression and recombinant $\mathrm{IL}-2$ induced proliferative response of purified Tac-positive T-cells. Mechanisms of Ageing Development 36, 223-241.

Saxena, R. K., Saxena, Q. B. \& Addler, W. H. (1988). Lectin-induced cytotoxic activity in spleen cells from young and old mice. Age-related changes in types of effector cells, lymphokine production and response. Immunology 64, 457-461.

Takeda, T., Hosokawa, M. \& Higuchi, K. (1991). Senescence-accelerated mouse (SAM): a murine model of accelerated senescence. Journal of the American Geriatric Society 39, 911-919.

Takeda, T., Hosokawa, M., Takeshita, S., Irino, M., Higuchi, K., Matsushita, T., Tomita, Y., Yasuhira, K., Hamamoto, H., Shimizu, K., Ishii, M. \& Yamamuro, T. (1981). A new murine model of accelerated senescence. Mechanisms of Ageing Development 17, 183-194.

Thoman, M. L. \& Weigle, W. O. (1981). Lymphokines and ageing: interleukin-2 production and activity in aged animals. Journal of Immunology 127, 2102-2105.

Thoman, M. L. \& Weigle, W. O. (1985). Reconstitution of in vivo cell-mediated lympholysis responses in aged mice with Interleukin 2. Joumal of Immunology 134, 949-952.

Toichi, E., Hanada, K., Hosono, M., Hosokawa, T., Hosokawa, M., Baba, S., Imamura, S. \& Takeda, T. (1994). Early decline in T-cell function in humoral immunity and long-lasting inflammatory T-cell activity in ageing SAM mice. In The SAM Model, Proceedings of the First International Conference on Senescence, pp. 175178 [T. Takeda, editor]. Amsterdam: Elsevier Science B.V.

Van Buren, C. T., Kulkarni, A. D., Fanslow, W. C. \& Rudolph, A. D. (1985). Dietary nucleotides, a requirement for helper/inducer T-lymphocytes. Transplantation 40, 694-697.

Van Buren, C. T., Kulkarni, A. D., Schandle, V. B. \& Rudolph, F. B. (1983). The influence of dietary nucleotides on cell-mediated immunity. Transplantation 44, 847-849.

Yoshioka, H., Yoshida, H., Doi, T., Muso, E., Ohshio, G., Higuchi, K., Inanda. M., Miyake, T., Kita, T., Hamashima, Y. \& Takeda, T. (1989). Autoimmune abnormalities in a murine model of accelerated senescence. Clinical and Experimental Immunology 75, 129-135. 